
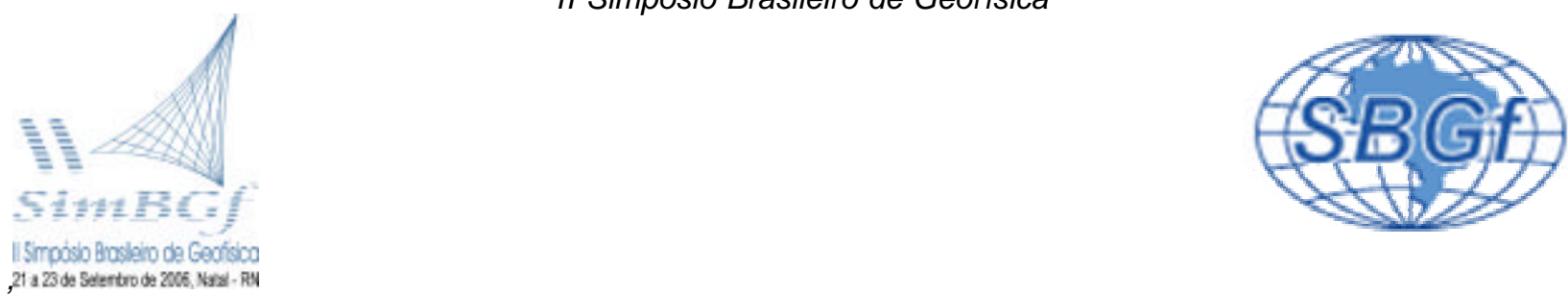

\title{
Construção e aplicações de um tomógrafo ultra-sônico para testemunhos de poços
}

José Agnelo Soares - Departamento de Geologia da UFRJ.

Copyright 2006, SBGf - Sociedade Brasileira de Geofísica

Este texto foi preparado para a apresentação no II Simpósio de Geofísica da Sociedade Brasileira de Geofísica, Natal, 21-23 de setembro de 2006. Seu conteúdo foi revisado pela Comissão Tecno-científica do II SR-SBGf mas não necessariamente representa a opinião da SBGf ou de seus associados. E proibida a reprodução total ou parcial deste material para propósitos comerciais sem prévia autorização da SBGt.

\section{Resumo}

Um inédito tomógrafo ultra-sônico para imageamento interno de testemunhos de poços foi projetado e construído. O referido equipamento gera tomogramas, em duas dimensões, que exibem a distribuição das velocidades das ondas elásticas $P$ e $S$ de seções retas de testemunhos de poços. O tomógrafo é composto por um sistema com 32 pistões de acionamento pneumático, cada um deles contendo um transdutor piezoelétrico independente. O tomógrafo é controlado por um programa de aquisição automática de dados, especialmente desenvolvido neste projeto. A fim de testar a capacidade do tomógrafo em gerar imagens internas de testemunhos, dois "testemunhos" artificiais foram preparados, sendo compostos por cimento Portland e possuem inclusões internas de rochas com tamanhos e formas previamente conhecidas. Os tomogramas registrados mostram claramente essas heterogeneidades internas. A técnica de imageamento por tomografia ultrasônica foi também aplicada em testemunhos reais de poços. Em um caso para controle composicional do testemunho em um estudo de tensões in situ, e em outro caso para mapear heterogeneidades e estruturas internas em testemunhos de rochas evaporíticas (sais). Neste caso os tomogramas ultra-sônicos foram comparados com os seus correspondentes tomogramas de raios $x$, mostrando as vantagens e limitações de cada técnica tomográfica. A técnica de tomografia ultra-sônica mostra-se muito promissora para o imageamento interno de testemunhos de poços e para o entendimento prático dos fenômenos que ocorrem na propagação de ondas elásticas no ambiente geológico.

\section{Introdução}

Testemunhos de poços são tradicionalmente imageados por tomografia de raios $\mathrm{x}$, mas a tomografia ultra-sônica de testemunhos apresenta a vantagem de usar o mesmo princípio físico do principal método de imageamento geológico de campo, ou seja, o método sísmico. É razoável esperar que tomogramas ultrasônicos exibam feições geológicas semelhantes àquelas vistas em seções sísmicas, apesar da diferença de escala. Em comparação com a tomografia de raios- $x$ a tomografia ultra-sônica apresenta imagens de mais baixa resolução, uma vez que atua na freqüência de $10^{5} \mathrm{~Hz}$ enquanto que
a tomografia de raios $x$ trabalha na freqüência de $10^{18} \mathrm{~Hz}$.

A tomografia ultra-sônica de testemunhos é muito útil na identificação de diversos atributos petrofísicos tais como composição mineral, heterogeneidade mineral, descontinuidades, homogeneidade na saturação de fluidos e distribuição interna de tensões em rochas. Esse método de investigação fornece mapas internos de distribuição de velocidade das ondas $P$ e $S$ de seções retas de testemunhos. Estes mapas reproduzem a distribuição dos atributos petrofísicos. Um tomograma elástico mostra, por exemplo, a superposição de um campo anisotrópico de tensões sobre uma amostra de rocha originalmente isotrópica.

A tomografia de transmissão é baseada na distribuição de transdutores em torno da seção reta do testemunho. Cada transdutor age como fonte e também como receptor. Em um dado momento, uma fonte atira contra outros transdutores que agem como receptores. $\mathrm{Na}$ aquisição de dados um grande número de formas de onda (uma para cada par fonte-receptor) é analisado quanto à identificação dos tempos de primeira quebra. Como são esperadas variações internas de velocidade no testemunho, uma grande quantidade de raios é necessária para a avaliação da distribuição de velocidades através do processo de inversão de dados.

Scott Jr et al. (1994) mostraram que é possível imagear a distribuição interna de tensões através de um experimento de tomografia ultra-sônica. Naquele trabalho os autores usaram um sistema de tomografia com 20 transdutores piezoelétricos colados em torno de uma seção reta do testemunho. A desvantagem de colar os transdutores no testemunho é que eles não podem ser re-utilizados na tomografia de outra seção reta do mesmo ou de outro testemunho, pois eles são danificados durante o processo de descolagem. Soares et al. (2004) apresentaram um estudo de simulação de tomografia ultra-sônica em testemunhos a fim de dar suporte técnico à construção do tomógrafo ultra-sônico para testemunhos de poços. Johnson (2004), em um estudo similar, desenvolveu e testou um sistema para aquisição laboratorial de dados de tomografia ultra-sônica.

\section{Tomografia de transmissão}

Para a realização de um experimento de tomografia ultrasônica um número definido de transdutores deve ser distribuído regularmente em torno do testemunho. Cada transdutor age, num determinado momento, como fonte ou como receptor. No momento em que um transdutor age como fonte os demais transdutores são receptores, 
embora alguns deles possam estar desativados naquele momento. O processo de aquisição de dados tomográficos consiste em controlar, a cada momento, qual transdutor age como fonte e quais deles são os receptores ativos. Esse processo termina quando cada um dos transdutores já tem agido uma vez como fonte. Neste projeto, 32 transdutores são regularmente distribuídos ao longo do perímetro do testemunho e, a cada momento, apenas os transdutores localizados no hemisfério oposto à fonte registram as ondas. Esse esquema adotado de aquisição de dados resulta no registro de 544 traços para cada tomograma. A fim de analisar a distribuição interna de velocidades em uma amostra de rocha se faz necessário esse elevado número de raios, sendo que quando mais complexo for o mapa interno de velocidades, maior o número de raios necessários ao seu correto reconhecimento. No caso de uma amostra perfeitamente homogênea, apenas um par de transdutores é suficiente para determinar a velocidade interna. Neste caso mais simples o experimento de tomografia seria absolutamente desnecessário. No entanto, a Natureza quase sempre apresenta um comportamento complexo.

As formas de onda registradas na aquisição de dados tomográficos têm o aspecto apresentado na Figura 1. As primeiras quebras de onda são identificadas em todas as 544 formas de onda registradas para cada tomograma, o que gera um vetor de tempos de propagação com 544 elementos, um valor de tempo para cada par fontereceptor.

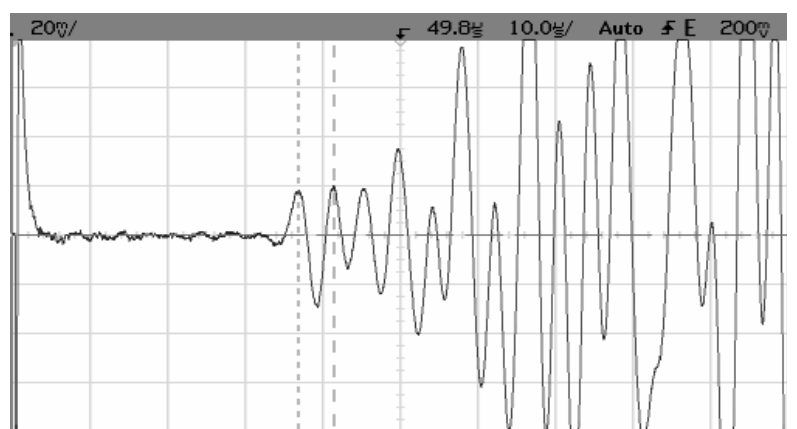

Figura 1 - Exemplo de uma forma de onda registrada no tomógrafo ultra-sônico para testemunhos de poços.

Para a inversão dos dados é preciso discretizar a área da seção reta do testemunho em um malha de pequenas células com velocidade de onda constante e previamente determinar o comprimento de cada segmento de raio dentro de cada célula. Esses comprimentos de segmentos de raio são os elementos não-nulos da chamada matriz Jacobiana. O conhecimento prévio dessa matriz é indispensável para o processo de inversão de dados e, supondo a propagação de ondas em raios retos, ela não muda, a menos que haja mudança na forma da seção reta do objeto a imagear, no número ou disposição dos transdutores, ou ainda na malha de células. A Figura 2 apresenta a malha de discretização (em preto) com 408 células, usada neste trabalho, bem como os 544 raios (em azul) cujas rotas são derivadas do esquema de aquisição adotado. 0 processo de inversão de dados busca definir um valor constante de velocidade para cada célula da malha de discretização que, no conjunto, honram os tempos totais de propagação medidos para cada par fonte-receptor. A solução encontrada no processo de inversão de dados não é única, mas representa um dos possíveis cenários que explicam os tempos registrados.

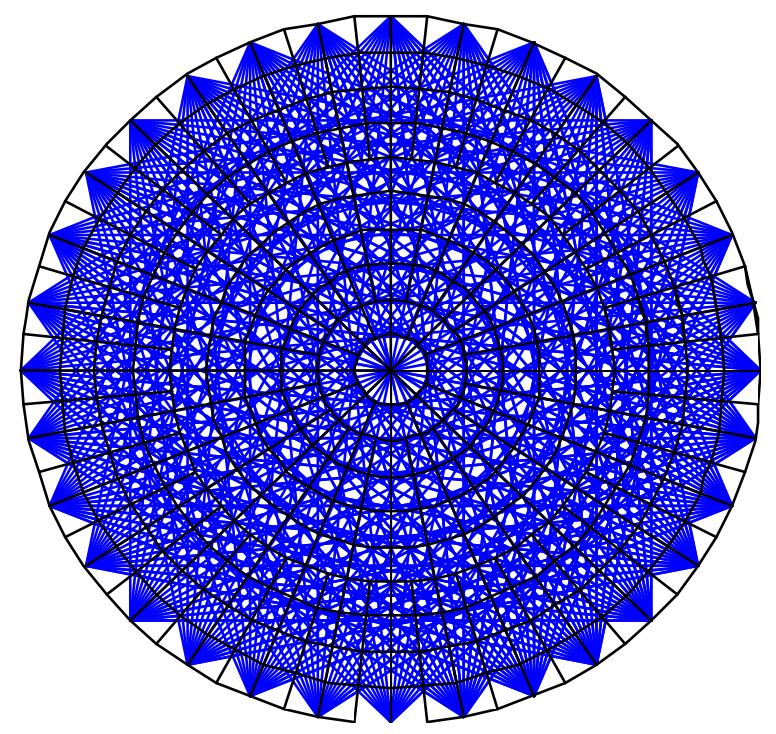

Figura 2 - Malha de discretização e esquema de distribuição de raios retos para 32 transdutores em torno do testemunho.

Os dados de tomografia podem ser organizados na seguinte forma:

$\left[\begin{array}{ccc}x_{11} & x_{12} \ldots x_{1 n} \\ x_{21} & x_{22} \ldots x_{2 n} \\ \vdots & \vdots & \vdots \\ x_{m 1} & x_{m 2} \cdots x_{m n}\end{array}\right] \cdot\left[\begin{array}{c}1 / v_{1} \\ 1 / v_{2} \\ \vdots \\ 1 / v_{n}\end{array}\right]=\left[\begin{array}{c}t_{1} \\ t_{2} \\ \vdots \\ t_{m}\end{array}\right]$

onde o primeiro elemento do lado esquerdo é a matriz Jacobiana e os demais elementos são os vetores de vagarosidades e de tempos, respectivamente. $\mathrm{O}$ índice $\mathrm{m}$ indica o número do raio e o índice $\mathrm{n}$ corresponde ao número da célula. A vagarosidade é o inverso da velocidade e o processo de inversão fornece como saída um valor de vagarosidade para cada célula da malha de discretização. Após a inversão de dados o vetor com 408 elementos de vagarosidade é convertido para um vetor de velocidades e seus valores são suavizados antes da geração do tomograma, o que evita tomogramas de aparência "pixelada". Neste trabalho foi implementado um algoritmo ART para a inversão dos dados.

\section{O tomógrafo ultra-sônico}

O sistema desenvolvido para tomografia ultra-sônica de testemunhos é inédito em todo o mundo, uma vez que 
permite a realização de inúmeras seções tomográficas utilizando o mesmo conjunto de transdutores, reduzindo drasticamente o custo financeiro e o tempo gasto na aquisição dos tomogramas. A Figura 3 apresenta uma vista geral do tomógrafo.

Neste equipamento 32 transdutores, de onda $P$ ou de onda S, são inseridos dentro de pistões de acionamento pneumático. O testemunho de rocha fica disposto verticalmente no centro do anel central, preso na base do equipamento, onde existe um mordente em forma de mandril. Os pistões se encontram regularmente distribuídos de forma radial em um grande anel metálico central. Quando os pistões são acionados na direção do interior do anel, eles tocam a superfície externa do testemunho, todos exercendo a mesma pressão sobre 0 testemunho. Para garantir um bom acoplamento acústico, sem provocar danos em amostras consolidadas, utilizase uma pressão pneumática de cerca de 100 psi.

Testemunhos mal consolidados não são apropriados para uso neste tomógrafo, a menos que sofram algum processo prévio de enrijecimento, como o congelamento, por exemplo. Já quando os pistões são recolhidos, o anel (com o conjunto de pistões) fica livre para ser deslocado verticalmente até a altura do novo corte tomográfico no testemunho. $\mathrm{O}$ anel central desloca-se por intermédio de um fuso central e um motor de passo, acionado por computador, instalado na parte superior do tomógrafo.

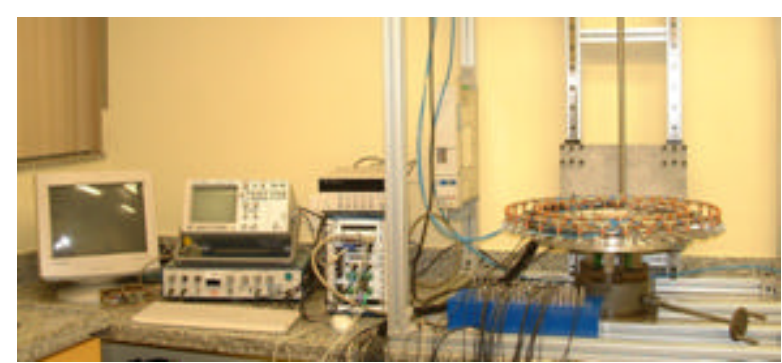

Figura 3 - Fotografia do tomógrafo ultra-sônico para testemunhos, projetado e construído neste projeto.

A freqüência central dos transdutores piezoelétricos utilizados neste equipamento é de $500 \mathrm{KHz}$, o que resulta numa resolução média da ordem de $5 \mathrm{~mm}$. O valor exato da resolução depende da velocidade e do fator de atenuação do material investigado, mas em linhas gerais, a resolução diminui em materiais com velocidades mais elevadas.

O sistema de controle e aquisição de dados é totalmente gerenciado por um computador industrial PXI, o qual contém vários componentes especializados para controle, aquisição, armazenamento e processamento de dados, como um osciloscópio digital, um chaveador automático com 200 canais, além de softwares para automação e controle.

O aparato eletrônico para geração e registro de ondas transmitidas consiste em um pulser-receiver de alta voltagem (até 400 Volts), cabos coaxiais, transdutores piezoelétricos, amplificador do sinal de saída e um osciloscópio digital para visualização das formas de onda e leitura dos tempos de trânsito das ondas.

\section{Resultados experimentais}

A fim de tes tar a capacidade do tomógrafo em reproduzir corretamente a distribuição interna de velocidades de sólidos cilíndricos como testemunhos de poços, dois "testemunhos" artificiais foram preparados usando cimento tipo Portland, com inclusões rochosas de forma e dimensões previamente conhecidas. Em um dos "testemunhos" de cimento foi introduzido um plugue de arenito com 1,5 polegada de diâmetro, como mostrado na Figura 4a. A Figura $4 \mathrm{~b}$ apresenta o correspondente tomograma de velocidade de onda $P$ (VP) registrado nesse "testemunho". No outro "testemunho" artificial de cimento foi introduzido um cubo de granito. A Figura 5a mostra a fotografia do topo do "testemunho" onde aparece o cubo de granito no seu interior, e a Figura $5 b$ é o correspondente tomograma de VP.
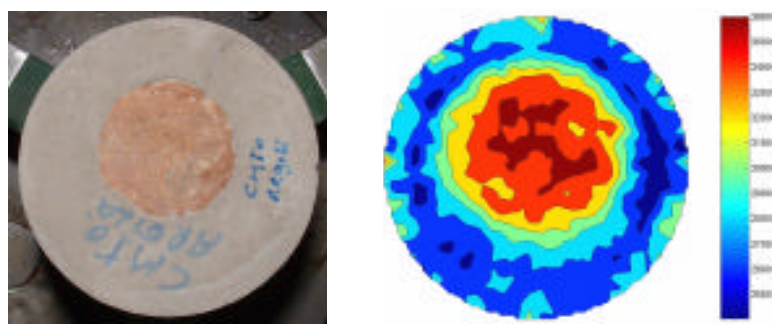

Figura 4 - a) Fotografia do "testemunho" artificial de cimento com uma inclusão cilíndrica de arenito; b) correspondente tomograma de velocidade de onda $P$.

A Figura 4 mostra que a tomografia ultra-sônica é capaz de identificar corretamente uma área circular central de alta velocidade (em torno de $3500 \mathrm{~m} / \mathrm{s}$ ), que corresponde ao plugue de arenito, circundada por uma zona de velocidade mais baixa (em torno de $2800 \mathrm{~m} / \mathrm{s}$ ) que corresponde à zona de cimento. Essas velocidades são compatíveis com as velocidades esperadas para o arenito e o cimento, respectivamente. A forma e o diâmetro da inclusão observada no tomograma são quase perfeitos, comprovando a excelente performance da técnica de tomografia ultra-sônica neste caso.
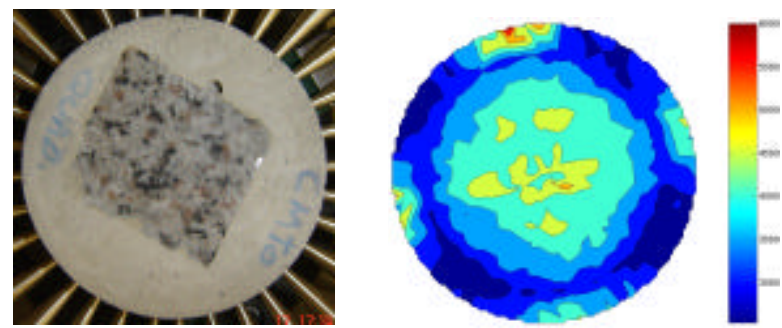

Figura 5 - a) Fotografia do "testemunho" artificial de cimento com uma inclusão cúbica de granito; b) correspondente tomograma de velocidade de onda $P$.

Da Figura 5 pode-se observar que a inclusão cúbica de granito também foi bem reproduzida. No entanto, o tomograma apresenta inesperadas zonas de alta velocidade nas regiões próximas das arestas do cubo. Esses artefatos são causados pelo fenômeno de difração da onda nas arestas do cubo. A difração da onda é uma característica intrínseca da propagação de ondas em bordas com dimensões iguais ou inferiores ao 
comprimento de onda. Como neste caso o comprimento de onda é da ordem de meio centímetro nas bordas do cubo, espera-se que ocorra o fenômeno de difração, reduzindo os tempos de trânsito e aumentando as velocidades nessas regiões. A ocorrência desse fenômeno é inevitável, mas o seu reconhecimento permite filtrá-lo, extraindo-o dos dados e evitando assim interpretações equivocadas.

Diversas técnicas de análise de tensões in situ foram aplicadas a dois testemunhos orientados de arenito de um poço vertical, conforme discutido em Bloch et al (2005). As técnicas aplicadas incluem AAA (Acoustic Anisotropy Analysis), que faz um mapeamento da anisotropia de VP. A aplicação da técnica AAA nesses testemunhos indicou 0 azimute da máxima tensão horizontal como sendo N41E para o testemunho A1 e $\mathrm{N} 43 \mathrm{E}$ para o testemunho A2. Os testemunhos $\mathrm{A} 1$ e $\mathrm{A} 2$ distam entre si cerca de 30 centímetros. Em uma rocha homogênea e intrinsecamente isotrópica, qualquer grau de anisotropia observada pode ser associado à ação de um campo anisotrópico de tensões. Um sério problema é quando a rocha não é homogênea. Neste caso a anisotropia medida pode ser parcialmente causada pela heterogeneidade. A tomografia ultra-sônica é proposta como uma técnica útil para entender o efeito da heterogeneidade da rocha sobre a sua anisotropia.

A Figura 6 apresenta o tomograma de VP registrado no testemunho A1, enquanto que a Figura 7 apresenta 0 tomograma de VP para o testemunho A2, os quais convergiram após 1000 iterações. Sobreposto a esses tomogramas é apresentado, em linhas cheias, 0 correspondente resultado da aplicação da técnica AAA: para cada azimute, a distância entre o centro da seção reta do testemunho e a linha cheia é proporcional ao tempo de trânsito entre um par transmissor-receptor diametralmente opostos. Dessa forma, em um sistema compressivo, a direção de maior tempo de trânsito corresponde à direção perpendicular à direção preferencial de microfraturamento por relaxação das tensões, ou seja, é a direção de máxima tens ão horizontal in situ.

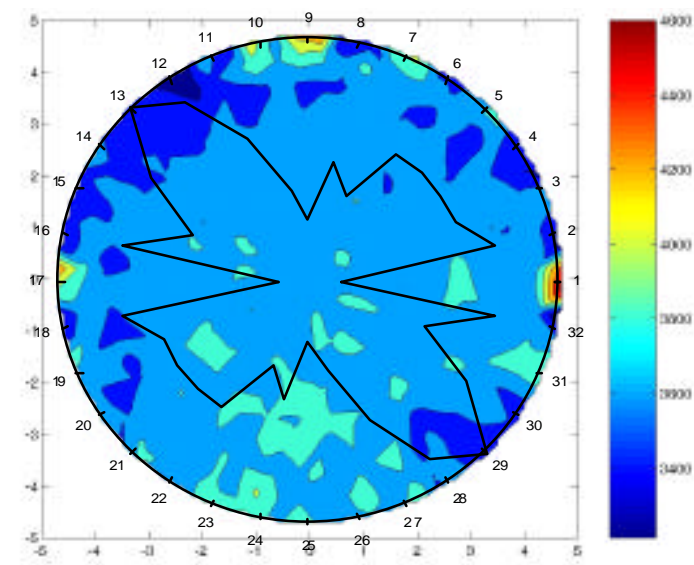

Figura 6 - Tomograma de velocidade da onda $P$ para $o$ testemunho A1. Superposto ao tomograma encontra-se, em linhas cheias, o resultado da técnica $A A A$.

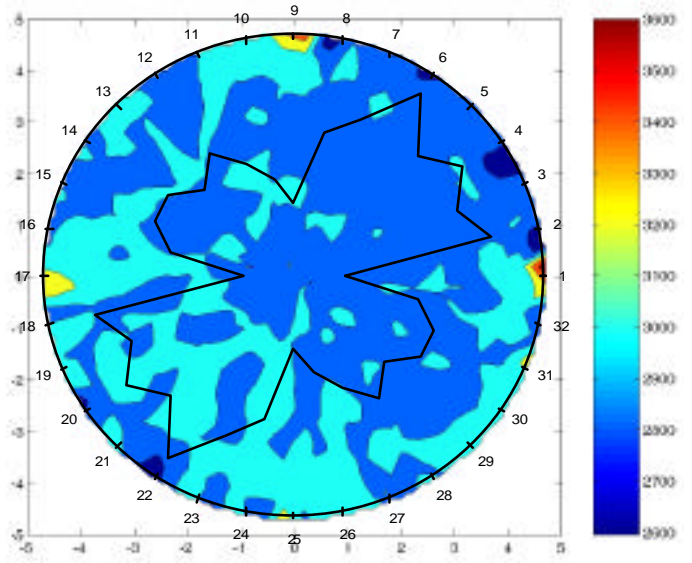

Figura 7 - Tomograma de velocidade da onda $P$ para 0 testemunho A2. Superposto ao tomograma encontra-se, em linhas cheias, o resultado da técnica $A A A$.

Embora os testemunhos A1 e A2 sejam verticalmente espaçados em apenas 30 centímetros, os resultados da técnica AAA indicam diferentes azimutes para a tensão máxima horizontal (N45W na Figura 6 e N56E na Figura 7). Analisando os tomogramas elásticos vê-se que esta grande variação na direção da tensão horizontal máxima indicada pela técnica AAA é devido à heterogeneidade dos testemunhos, o que é reforçado pelo tomograma de velocidade da onda $S$ apresentado na Figura 6. A anisotropia resultante da heterogeneidade composicional do material causa inconsistência na análise do campo de tensões in situ. $O$ conhecimento do padrão de heterogeneidade do testemunho submetido à técnica AAA, ou qualquer outra técnica de avaliação das tensões in situ baseada na anisotropia do testemunho, somente pode ser obtido através da tomografia do testemunho. A tomografia ultra-sônica tem a vantagem de mensurar a mesma grandeza física da técnica $A A A$, o que não ocorre com a tomografia de raios $x$. Conseqüentemente, a obtenção de um tomograma ultra-sônico é essencial para a correta interpretação do padrão de anisotropia observado em um testemunho.

Três amostras de testemunhos de halita e três amostras de testemunhos de carnalita foram submetidas à tomografia ultra-sônica. As amostras são discos de rocha com aproximadamente $3 \mathrm{~cm}$ de espessura, cortados de testemunhos de poços. Os tomogramas são planos imageados na metade da espessura das amostras. Com o objetivo de comparar os resultados obtidos com os de outra técnica, todas as amostras foram também submetidas ao imageamento através de tomografia de raios x. A Figura 8 apresenta fotografias das três amostras de halita, os tomogramas de velocidade da onda $\mathrm{P}$ e seus correspondentes tomogramas de raios $\mathrm{X}$. A Figura 9 apresenta os mesmos dados para as amostras de carnalita.

O comportamento geral apresentado pelos tomogramas das Figuras 8 e 9 pode ser sumarizado como segue:

Os testemunhos de halita são, em geral, mais homogêneos do que os de carnalita, apresentando 
velocidade média da onda $P$ de $4000 \mathrm{~m} / \mathrm{s}$, velocidade mínima de 3500 m/s e velocidade máxima de 4500 m/s.

Eventos lineares de alta velocidade, observados em duas das amostras de halita, foram interpretadas como sendo linhas suturadas de fraturas pré-existentes.

Os testemunhos de carnalita são bastante heterogêneos, sendo na verdade misturas de carnalita e halita. As áreas do testemunho com predominância de halita exibem velocidade da onda $P$ em torno de $4000 \mathrm{~m} / \mathrm{s}$, enquanto que $\boldsymbol{x}$ áreas onde a carnalita predomina apresentam velocidades próximas de $3500 \mathrm{~m} / \mathrm{s}$. Uma amostra de carnalita mostrou, em seu tomograma ultra-sônico, um evento linear com baixa velocidade na sua região central. Este evento parece representar uma linha de fratura préexistente cuja sutura se deu de forma incompleta ou que foi reativada.

A tomografia ultra-sônica é muito mais sensível à presença de descontinuidades no meio do que a tomografia de raios $x$. Isto se torna evidente pela ausência dos eventos lineares nos tomogramas de raios $x$. Descontinuidades muito pequenas, como microfissuras, afetam substancialmente a propagação de ondas elásticas, mas quase não afetam radiações eletromagnéticas como os raios $x$.

A resolução da tomografia de raios $x$ é muito superior à resolução da tomografia ultra-sônica. Isto ocorre porque a freqüência dos raios $x$ é da ordem de $10^{18} \mathrm{~Hz}$, com comprimentos de ondas da ordem de $10^{-7} \mathrm{~mm}$, enquanto que as freqüências ultra-sônicas são da ordem de $10^{3}$ $\mathrm{Hz}$, com comprimentos de onda de alguns milímetros.

\section{Conclusões}

Um inédito equipamento para tomografia ultra-sônica de testemunhos foi projetado, construído e testado com sucesso em amostras artificiais e reais. Foram utilizados 32 transdutores piezoelétricos radialmente distribuídos em torno da seção reta do testemunho, e uma malha com 408 elementos radiais, para a discretização da seção reta do testemunho durante o processo de inversão de dados, foi adotada.

A resolução da técnica de tomografia elástica é inferior à resolução da tomografia de raios $x$, o que limita a sua capacidade para o imageamento de camadas muito finas. Outra característica importante da tomografia elástica é a possível ocorrência de difração de onda em superfícies com ângulo de curvatura menor que o comprimento de onda. Por isso, inclusões com formas suaves são corretamente imageadas, ao passo que inclusões com bordas angulosas tendem a ser imageadas com deformações aparentes.

Em freqüências ultra-sônicas, a técnica de tomografia elástica foi aplicada com sucesso no imageamento de testemunhos artificiais e reais. Neste trabalho foi assumida a simplificação dos raios retos. Graças à grande cobertura de raios, os efeitos deletérios desta simplificação não afetaram substancialmente a qualidade dos tomogramas obtidos, exceto na presença de contrastes muito fortes de velocidade. A aplicação da tomografia ultra-sônica em testemunhos artificiais com inclusões previamente conhecidas comprovou a habilidade da técnica para reconhecimento desse tipo de feição tão comum no ambiente geológico. No caso de uma inclusão cúbica de granito, o correspondente tomograma elástico apresentou artefatos na vizinhança das arestas do cubo, o que foi interpretado como decorrência do fenômeno de difração da onda.

Tomografia ultrasônica aplicada a testemunhos reais de arenito mostrou que a técnica é muito útil para a avaliação da homogeneidade dos testemunhos, desempenhando um papel único e fundamental na identificação das possíveis causas de anisotropia de velocidades elásticas. Vários métodos de determinação das tensões in situ, os quais são baseados na análise de anisotropia de testemunhos (como AAA e ASR) deveriam sempre ser acompanhados de uma tomografia ultrasônica a fim de avaliar os efeitos da heterogeneidade dos testemunhos sobre os resultados dos métodos de análise.

Quando a tomografia ultra-sônica foi aplicada em testemunhos reais de rochas evaporíticas, eventos lineares internos foram identificados sem que os mesmos fossem vistos nos tomogramas obtidos por tomografia de raios $x$. Esses eventos lineares foram interpretados com linhas de sutura em planos de fraturas pré-existentes. Apesar da resolução mais elevada da tomografia de raios $x$, a propagação de ondas elásticas é muito mais sensível à presença de descontinuidades no meio, em comparação com a tomografia de raios $\mathrm{x}$. Portanto, as técnicas de tomografia ultra-sônica e de tomografia de raios $x$ são técnicas complementares de imageamento interno de rochas.

\section{Agradecimentos}

O autor agradece a PETROBRAS pelo suporte financeiro e técnico a este projeto, cessão de testemunhos e permissão para publicação dos resultados.

\section{Referências}

Bloch, M.; Freitas, S.M.S.; Souza, M.S.; Soares, J.A.; Bacelar, C.J.R. (2005). In-situ stress determination based upon borehole imaging and rock-sample analyses: a comparison among anelastic strain recovery (ASR), acoustic velocity, and acoustic tomography. 2005 SPE Conference. Rio de Janeiro.

Johnson, W.B. (2004). Design and testing of a laboratory ultrasonic data acquisition system for tomography. Thesis. Virginia Polytechnic Institute and State University, USA. 98 pp.

Scott Jr, T.E.; Ma, Q. ; Roegiers, J.C. ; Reches, Z. (1994). Acoustic tomographic difference imaging of dynamic stress fields. Proc. of Eurock'94 Conference, pp 99-104. Balkema, Rotterdam.

Soares, J.A.; Silva, J.C.; Martins, J.L; Bloch, M.; Oliveira, M.S. (2004). Ultrasonic Tomography in cores. EAGE 66th Conference and Exhibition. Paris. 

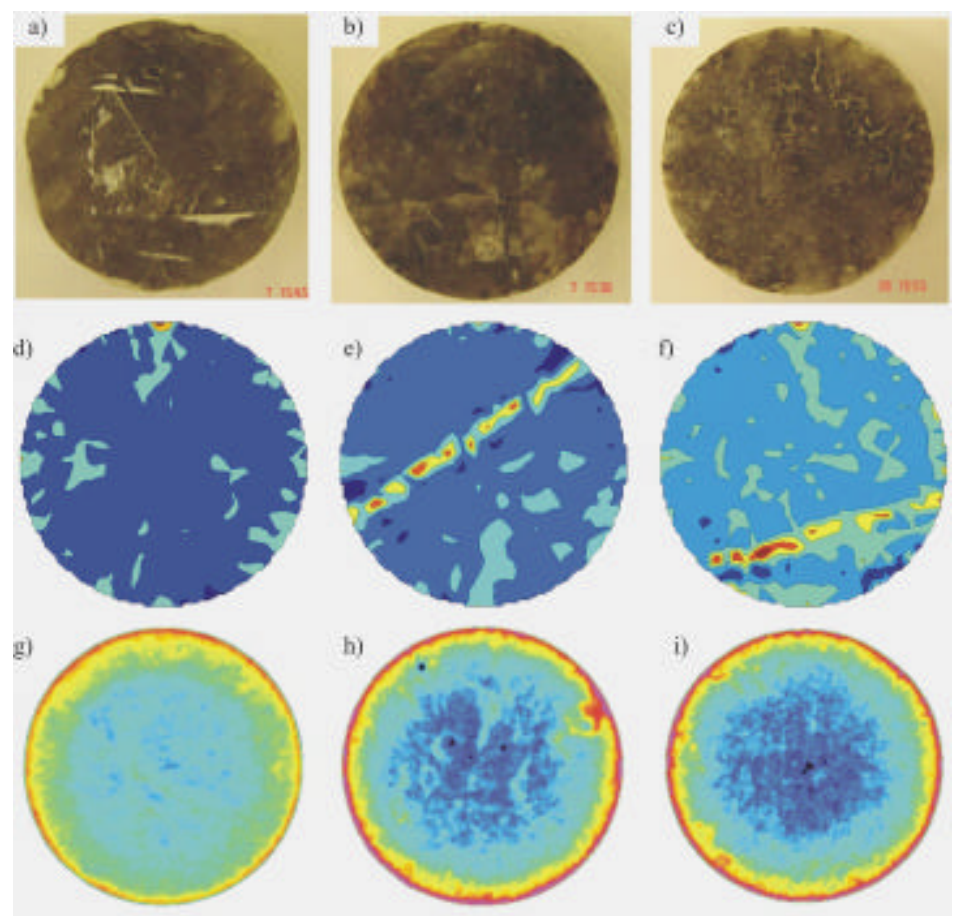

Figura 8 - a) Amostra 1 de halita. b) Amostra 2 de halita. c) Amostra 3 de halita. d) Tomograma de VP para a amostra 1.e) Tomograma de VP para a amostra 2. f) Tomograma de VP para a amostra 3. g)Tomograma de raios $x$ para a amostra 1.h) Tomograma de raios $x$ para a amostra 2. i) Tomograma de raios $x$ para a amostra 3.
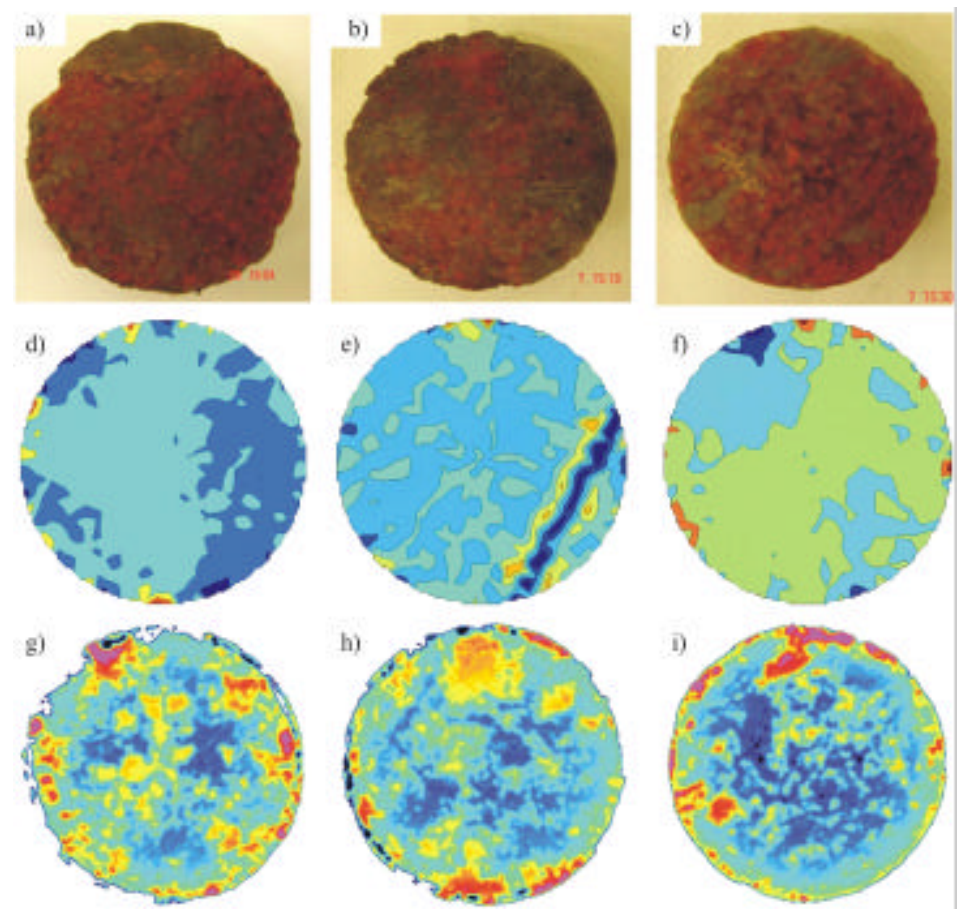

Figura 9 - a) Amostra 1 de carnalita. b) Amostra 2 de carnalita. c) Amostra 3 de carnalita. d) Tomograma de VP para a amostra 1. e) Tomograma de VP para a amostra 2. f) Tomograma de VP para a amostra 3. g)Tomograma de raios $x$ para a amostra 1. h) Tomograma de raios $x$ para a amostra 2. i) Tomograma de raios x para a amostra 3. 